\title{
Rising air temperatures will increase intertidal mussel abundance in the Arctic
}

\author{
Jakob Thyrring ${ }^{1,2, *}$, Martin E. Blicher ${ }^{3}$, Jesper G. Sørensen ${ }^{1,4}$, Susse Wegeberg ${ }^{5,6}$, \\ Mikael K. Sejr ${ }^{1,2}$ \\ ${ }^{1}$ Arctic Research Centre, Department of Bioscience, Aarhus University, Ny Munkegade 114, Building 1540, \\ 8000 Aarhus C, Denmark \\ ${ }^{2}$ Marine Ecology, Department of Bioscience, Aarhus University, Vejlsøvej 25, 8600 Silkeborg, Denmark \\ ${ }^{3}$ Greenland Climate Research Centre, Greenland Institute of Natural Resources, Nuuk, Greenland \\ ${ }^{4}$ Section for Genetics, Ecology and Evolution, Department of Bioscience, Aarhus University, Ny Munkegade 116, \\ Building 1540, 8000 Aarhus C, Denmark \\ ${ }^{5}$ Arctic Research Centre, Department of Bioscience, Aarhus University, Frederiksborgvej 399, Building I2.17, \\ 4000 Roskilde, Denmark \\ ${ }^{6}$ Arctic Environment, Department of Bioscience, Aarhus University, Frederiksborgvej 399, Building I2.17, 4000 Roskilde, \\ Denmark
}

\begin{abstract}
Knowledge about the consequences of Arctic warming for marine biogeography remains limited. Mytilus mussels play a key ecological role in the littoral zone, and they are expected to be sensitive to climate change. Here we used a space-for-time approach as a first attempt to infer the coupling between climate warming and population structure and abundance of intertidal mussels along a latitudinal climate gradient in west Greenland. We analysed trends in air temperatures, collected seasonal temperature data from intertidal microhabitats, and quantified abundance, growth and age structure at 73 sites in 5 fjords. We also compared tolerance to sub-zero temperatures between seasons and latitudes. Since 1958, atmospheric temperatures have increased significantly in all fjords. Consequently, the number of days with temperatures below the lower lethal temperature, $\mathrm{LT}_{50}\left(-13^{\circ} \mathrm{C}\right)$, has decreased by up to $57 \%$, suggesting that constraint by low temperature is weakening. Abundance declined $>95 \%$ with increasing latitude from an average of 23.67 to 0.71 ind. $0.0625 \mathrm{~m}^{-2}$ in mid-intertidal habitats. However, no latitudinal differences in growth, average size $(6.3-9 \mathrm{~cm})$, age $(1.5-2.5 \mathrm{yr})$ and mortality $\left(55.9-62.5 \mathrm{yr}^{-1}\right)$ were found. The abundance of $1 \mathrm{yr}$ old recruits declined with latitude, indicating that geographical patterns are controlled at the earliest life stages. Air temperatures and exposure time were important drivers for latitudinal patterns in abundance, with adults being increasingly limited to favourable microhabitats in the lower intertidal to the North. Combined, the data suggest that increased warming will facilitate an increase in intertidal mussel abundance in Greenland, and potentially, across the Arctic.
\end{abstract}

KEY WORDS: Latitudinal gradient · Greenland $\cdot$ Baseline data $\cdot$ Space-for-time $\cdot$ Climate change $\cdot$ Mytilus $\cdot$ Temperature $\cdot$ Thermal tolerance

\section{INTRODUCTION}

Anthropogenic induced climate change has impacted abundances and redistributed species, resulting in local biodiversity loss, species extinctions or

${ }^{*}$ Corresponding author: thyrring@bios.au.dk introductions and regime shifts (Sorte et al. 2010, Pimm et al. 2014). In the northern hemisphere, most climate change studies have been conducted at lower latitudes, with the common focus to study negative impacts of increasing temperatures at or near

(C) The authors 2017. Open Access under Creative Commons by Attribution Licence. Use, distribution and reproduction are unrestricted. Authors and original publication must be credited. 
the southern end of a species range. For instance, the equator-ward distribution limit of blue mussels Mytilus edulis has contracted $>350 \mathrm{~km}$ in response to warming (Jones et al. 2010), retracted their intertidal vertical distribution (Harley 2011), and it has declined in abundance by $>60 \%$ since the 1970 s in the Gulf of Maine (Sorte et al. 2017). Thus, an understanding of the effects of climate change at lower latitudes are slowly emerging. However, the effects of climate change on temperate species at higher latitudes (such as in the Arctic) have received less attention. Consequently, the impacts of climate change in the Arctic, especially in Greenland, remain understudied (Wassmann et al. 2011) even though the region is experiencing warming at rates 2- to 3-fold greater than the global average (AMAP 2017).

Arctic warming affects species directly (e.g. by affecting physiological performance) or indirectly (e.g. though shifts in biological interactions or habitat alteration). For instance, warming diminishes the sea ice extent, which negatively impacts Arctic species associated with sea ice ecosystems (Wassmann et al. 2011). Arctic warming therefore negatively affects the abundance of some Arctic species, while potentially benefiting temperate species (e.g. through increased growth, abundance and biodiversity) as poleward geographical ranges expand and new habitats become available (Wȩsławski et al. 2010, Poloczanska et al. 2016, Marbà et al. 2017). Thus, the potential positive effects on temperate species at their poleward distribution edge need to be studied further.

The rocky intertidal zone is a model system well suited to study climate change impacts as organisms are restricted to a narrow coastal habitat where they are directly exposed to atmospheric warming (Helmuth et al. 2006). The intertidal zone of Greenland has received little attention, although Greenland has a $\sim 2400 \mathrm{~km}$ long coastline with a north-south climate gradient from the subarctic into the High Arctic. Along this coastline, oceanographic conditions gradually change to Arctic in terms of sea ice cover extent (a map displaying winter and summer sea ice extent can be found in Supplement 1 at www.int-res.com/ articles/suppl/m584p091_supp.pdf), ocean and air temperatures and length of the period with primary production (Sejr et al. 2009, Krause-Jensen et al. 2012). Because only few quantitative studies have been conducted in this intertidal zone (Hansen 1999, Blicher et al. 2013, Høgslund et al. 2014), preliminary research should focus on foundation species because of their importance for ecosystems. Foundation species include shell-forming molluscs as they create hard substrates increasing the abundance of a diverse associated fauna (Gutiérrez et al. 2011, Thyrring et al. 2015b). In west Greenland, M. edulis and $M$. trossulus (hereafter referred to as Mytilus) are 2 common foundation species that both form mussel beds, hereby providing microhabitats and food for a diverse associated fauna (Mathiesen et al. 2017).

Because climate-induced changes in Mytilus populations can affect community structure in Greenland's intertidal zone, this study aims to characterize the abundance and population dynamic patterns of Mytilus along the west coast of Greenland to their poleward edge, and further, to provide a first indication of how climate change may negatively affect or benefit them in a warmer future. One way to evaluate climate impacts on species level is by comparing historical and current survey data to track changes. However, because no time-series are available for the Greenland intertidal, we substituted temporal changes with spatial patterns by applying a spacefor-time approach to infer temporal changes (Pickett 1989, Blois et al. 2013). Furthermore, Mytilus has a wide distribution in Greenland, and different populations are likely exposed to different daily, seasonal and annual variation in air temperatures. Such differences could lead to adaptive variance, e.g. in cold tolerance, with Arctic populations being more coldtolerant than more southern ones. This adaptation is important for understanding population dynamics and abundance patterns. This study therefore aims to (1) quantify and evaluate differences in the abundance and growth of Mytilus mussels from 5 locations in west Greenland $\left(64^{\circ}-77^{\circ} \mathrm{N}\right)$; (2) evaluate intra-specific cold tolerance among seasons and locations; and (3) give a first indication of possible effects of continued Arctic warming on Mytilus abundance and distribution in Greenland.

\section{MATERIALS AND METHODS}

\section{Field sampling}

We collected mussels at 73 sites divided between 5 different locations along the south-north orientated intertidal zone cline of west Greenland. Abundance data from 15 sites around Nuuk (collected in June 2011) were obtained from Blicher et al. (2013). We further collected animals at 12 sites on Disko Island (August 2012), 18 sites around Uummannaq (July 2012), 13 sites around Upernavik (July 2013) and 15 sites around Qaanaaq (August 2014) (Fig. 1). 


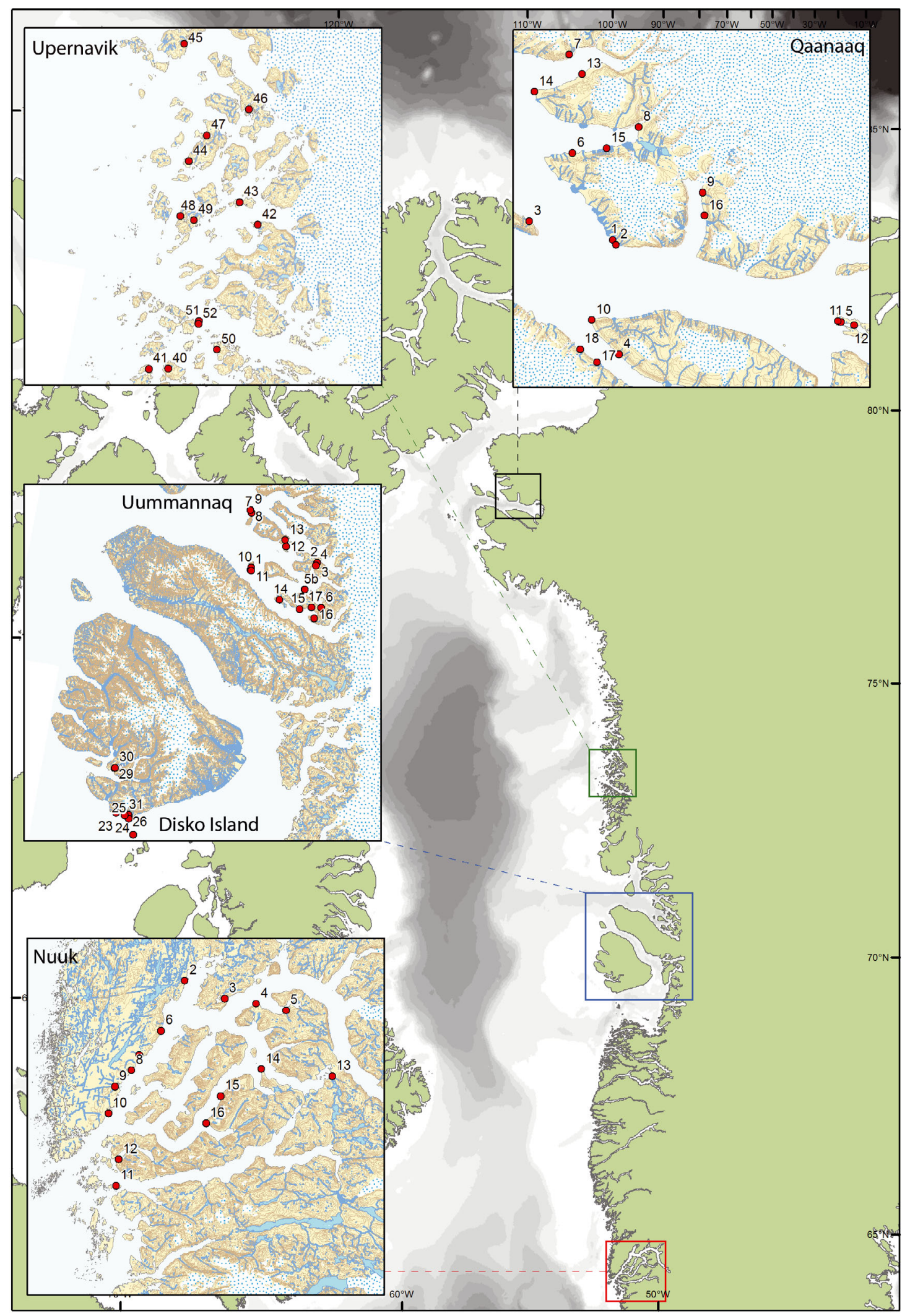

Fig. 1. Position of 73 sampling sites nested within 5 locations in west Greenland: Nuuk (red square), Disko Island and Uummannaq (blue square), Upernavik (green square) and Qaanaaq (black square) 
Sampling was performed over consecutive years during summer due to the logistic restraints associated with working in the Arctic. However, at each location, we found established Mytilus populations (see 'Results'). We therefore assume that inter-annual variation in recruitment success can be neglected, and because Mytilus spp. are relatively long-lived semi-sessile animals, short-term temporal variation in adult abundance can be considered limited.

We focused surveys on flat open rocky intertidal shores in fjord systems from the subarctic to the High Arctic region $\left(64-77^{\circ} \mathrm{N}\right)$ to reflect the gradual change in environmental conditions, e.g. temperature and sea ice. Because local topography over the scale of centimeters can affect the abundance and biomass of intertidal mussels by order of magnitudes (Kostylev \& Erlandsson 2001, Blicher et al. 2013), a sampling regime was designed specifically to capture this variation, thus allowing mussel collection in similar and comparable habitats at each sampling site. To ensure similar sites were sampled, the overall physical environment (ice scour, rugosity and orientation) was assessed visually at each site (detailed results on all environmental parameters are in Supplement 2). Furthermore, a wave exposure index was calculated following Blicher et al. (2013). In short, the distance to nearest shoreline was calculated in 8 directions ( $N, N E, E, S E, S, S W, W$ and NW) from each of our sampling sites. The estimated distance to nearest shore in each of the 8 directions was then multiplied by the wind impact factor, which was calculated for each direction as:

Wind impact $=$ Frequency $\times$ Average wind speed

where only wind speeds $>10 \mathrm{~m} \mathrm{~s}^{-1}$ were considered important for wave generation and using hourly data obtained from local weather stations. The final wave exposure index for each sampling station was calculated as shoreline distance $(\mathrm{m}) \times$ wind impact factor $\left(\mathrm{m} \mathrm{s}^{-1}\right)$ in each of the 8 directions and summed (see Supplement 2).

Mussels were collected during low tide using horizontal rope transects placed parallel to the shoreline at the mid-intertidal level (MTL). MTL transect positions were located using a wooden folding ruler placed at the low water mark and a hand leveller to point out transects height, which was calculated from the Greenlandic tidal table (www.dmi.dk). Each site was represented by 7 to 10 replicate samples with a surface area of $0.0625 \mathrm{~m}^{2}$, placed along the rope with $0.25 \mathrm{~m}$ distance. At the 2 northernmost sites (Upernavik and Qaanaaq), mussels were collected in the MTL, and in addition, mussels were collected along another hori- zontal rope transect placed parallel to the shoreline $30 \mathrm{~cm}$ below the MTL transect (termed MTL - 30). Furthermore, because mussels were found extremely scattered in Qaanaaq, we supplemented the 2 transects (MTL and MTL - 30) with a search of $4 \mathrm{~m}^{2}$ in the lowest intertidal zone (LTZ) at each site in Qaanaaq.

For each sample, at each site, the number of mussels was counted. We measured shell length to nearest $\mathrm{mm}$ with digital calipers, and the wet weight was determined to nearest $0.001 \mathrm{~g}$. To determine age, we counted surface growth rings on each shell because they represent cessation of shell growth during winter (Blicher et al. 2013). Individuals with 1 winter growth band were termed 1 yr old recruits, while 0 yr old mussels without any growth bands were identified as spat.

\section{Temperature measurements}

To measure intertidal microhabitat temperatures, temperature loggers (HOBO professional, Onset) were placed in the intertidal zone at each of the 5 sampling locations. Loggers were placed near observed mussels to measure habitat temperatures. All temperature loggers were collected after approximately 1 yr. Atmospheric temperatures were derived from local weather stations in Nuuk (Stn 4250); Disko Island (Stn 4220/4224); Uummannaq (Stn 4212/4213); Upernavik (Stn 4209/4210/4211) and Qaanaaq (Stn 4201/4205). These data are available from the Danish Meteorological Institute, www.research.dmi. $\mathrm{dk}$, and a description can be found in Boas \& Wang (2011). There is in general a strong correlation between the extreme daily minimum temperature and mean temperature of the day (Griffiths et al. 2005). Therefore, based on atmospheric temperature time series for each location, we calculated the annual number of cold days where mean air temperatures were below $-13^{\circ} \mathrm{C}$ for at least $1 \mathrm{~h}$. We did so because the cold tolerance experiments (described below) showed $-12.8^{\circ} \mathrm{C}$ to be the temperature where $50 \%$ $\left(\mathrm{LT}_{50}\right)$ of Mytilus mussels died following $2 \mathrm{~h}$ of exposure to sub-zero air temperatures.

\section{Experimental protocol}

Animal collection and holding conditions

To investigate the capacity of Mytilus mussels to adjust their cold tolerance among populations and seasons, we conducted a common-garden experiment in 
which collected animals were allowed to acclimate to laboratory conditions for $8 \mathrm{~d}$ before experiments were conducted. This method captures the part of cold tolerance that is due to physiological plasticity but not the effects of abiotic conditions (e.g. exposure time to air temperatures and thermal history) (Nuismer \& Gandon 2008, Kuo \& Sanford 2009). This method is therefore useful to inform about physiological differences among populations and seasons, but the results should not be used to directly define how species will respond to a given change in environmental temperatures. Intertidal mussels were collected during August in Nuuk and during July in Uummannaq. Seasonally acclimatized mussels were collected in Nuuk in April (spring) and August (summer) 2011 because mussels prior to these months had been exposed to winter and summer conditions, respectively. Collected animals (size 32.1$51.2 \mathrm{~mm}$ ) were immediately transferred to aerated tanks. Water temperature was maintained at $8^{\circ} \mathrm{C}$ (for mussels collected in summer) and $1^{\circ} \mathrm{C}$ (for mussels collected in spring) to represent the habitat temperature at time of collection. Water volume was regularly exchanged with fresh filtrated seawater to minimise build-up of pseudofeces and excretion products.

\section{Cold tolerance}

To determine cold tolerance (i.e. survival to subzero temperature exposure) of intertidal mussels exposed to air temperatures at low tide, we tested survival of 10 individuals at each of 10 experimental temperatures (ranging from -10 to $-15^{\circ} \mathrm{C}$ ), which are common winter temperatures in Greenland (Thyrring et al. 2015a). Exposure to experimental temperature was either 1, 2 or $4 \mathrm{~h}$. Experiments were conducted in programmable waterbaths (Hetofrig, Birkerød, Denmark), which allowed us to control temperature within $\pm 0.1^{\circ} \mathrm{C}$. Mussels were placed in individual $50 \mathrm{ml}$ plastic vials in the waterbath, and temperature was lowered from the holding temperature to the experimental temperature at a constant rate over $15 \mathrm{~min}$. After each experiment, mussels were returned directly to the holding tanks. Mussels were considered dead if they failed to close their shells after tactile stimuli $48 \mathrm{~h}$ after exposure to sub-zero temperatures.

\section{Statistical analysis}

Data exploration and model selection was carried out following Zuur et al. (2010), and all statistical tests were conducted using R (R Core Team 2017).
Boxplots were used to check for potential outliers and homogeneity, while normality was investigated by histograms. We found no indications of zero-inflation or over-dispersion of abundance data. The abundance data set consists of mussels collected from multiple sampling sites ( $\mathrm{n}=12-18$, described above) nested within 5 fjords in west Greenland (see Fig. 1). To examine patterns, we therefore applied a generalized mixed effect model (GLMM) with a Poisson distribution in which 'sampling sites' was used as a random intercept, as this accounted for dependency among sites located within a fjord (Zuur \& Ieno 2016).

To investigate effects of geographic location, shell size, season and exposure time on survival, we decided to use generalized linear models (GLMs) with a binomial distribution (McCullagh \& Nelder 1989). A GLM with a Poisson distribution was used to examine the effects of within-site vertical zonation on abundance. Finally, using the 'mcgv' package in $\mathrm{R}$, a series of generalized additive models (GAMs) that incorporated temporal correlation, was applied to examine temporal trends in atmospheric temperatures (Zuur 2012).

Average annual mortality rates were calculated by applying a negative exponential mortality model:

$$
\mathrm{N}_{t}=\mathrm{N}_{1} \times \mathrm{e}^{(-Z \times t)}
$$

where $\mathrm{N}_{1}$ is the number of mussels in age class $1, \mathrm{~N}_{t}$ is the numbers at age $t$ (year), and $Z$ is the mortality rate (Blicher et al. 2013). Blicher et al. (2013) found that mortality rates in Mytilus gradually are reduced with age, especially at age $>10 \mathrm{yr}$. To avoid a bias of age in our mortality rate estimates, we calculated mortality rates in 3 sub-groups: age $<5$; age 5 to 10 ; age $>10 \mathrm{yr}$, if a specimen above age $10 \mathrm{yr}$ was found (Blicher et al. 2013). If no specimens above age $10 \mathrm{yr}$ were found, one mortality estimate was calculated; this approach was to ensure that the data sets for age $<10 \mathrm{yr}$ had an adequate number of observations to provide reliable mortality estimates. Because age structure did not follow a normal distribution, we used the non-parametric Kruskal-Wallis test to analyse differences among fjords.

\section{Growth pattern analysis}

Based on size-at-age data, we analysed the growth patterns of Mytilus spp. in west Greenland. The analysis follow the protocol described by Blicher et al. (2013). In short, the model was based on maximum likelihood estimation (Berry \& Lindgren 1996), and an initial model proposed that growth would fol- 
low a sigmoidal growth curve of the Richards family (Richards 1959, Sugden et al. 1981, Blicher et al. 2007):

$$
S_{t}\left(S_{\infty}, m_{1} t_{*}, T\right)=S_{\infty}\left[1-(1-m) \exp \left\{\frac{-\left(t-t_{*}\right)}{T m^{m /(1-m)}}\right\}\right]^{1 /(1-m)}
$$

where $S_{\infty}$ is the asymptotic shell length $(\mathrm{mm}), t$ is individual age (yr), $t_{*}$ is an age-at-growth inflexion, $T$ (yr) is the time needed to grow from zero to $S_{\infty}$ at maximum growth rate, and $m$ is a shape factor for Richards curves. An $m \rightarrow 0$ corresponds to von Bertalanffy growth, $m \rightarrow 1$ to Gompertz, and $m=2$ to single logistic (see Supplement 3 for a full model description).

\section{RESULTS}

\section{Temperatures}

West Greenland has mixed semi-diurnal tidal cycles. The average daily exposure time to air temperatures during low tide in the MTL ranged from 5.8 to $10.2 \mathrm{~h}$ (Table 1). The largest range in air exposure time was found in the Uummannaq MTL with a minimum of $4.7 \mathrm{~h}$ and a maximum of $19.2 \mathrm{~h}$ (Table 1).

Annual average atmospheric temperatures measured from weather stations in the years 2000-2011 ranged from $-0.22^{\circ} \mathrm{C}$ (Nuuk), $-2.54^{\circ} \mathrm{C}$ (Disko Island), $-3.32^{\circ} \mathrm{C}$ (Uummannaq), $-5.33^{\circ} \mathrm{C}$ (Upernavik) to $-8.78^{\circ} \mathrm{C}$ (Qaanaaq). The number of days per year with temperatures below $-13^{\circ} \mathrm{C}$ increased from $11 \mathrm{~d}$ in Nuuk to $169 \mathrm{~d}$ in Qaanaaq (Table 2). On a temporal scale, the GAM analysis revealed a statistically significant positive increase in atmospheric temperature in Nuuk (from 1958-2014, $F_{1,55}=3.41$, $\mathrm{p}=0.0072$; Fig. 2a), on Disko Island (from 1958-2014: $F_{1,55}=6.33, \mathrm{p}<$ 0.0001. Fig. 2b), in Uummannaq (from 2000-2014: $F_{1,13}=2.34, \mathrm{p}<0.0001$; Fig. 2c), in Upernavik (from 19952014: $F_{1,19}=6.30, \mathrm{p}=0.0075$, Fig. $2 \mathrm{~d}$ ) and in Qaanaaq (from 1995-2014: $F_{1,19}=2.21, \mathrm{p}<0.0001$; Fig. 2e), which resulted in a significant decline in the number of days with temperatures below $-13^{\circ} \mathrm{C}$ in Nuuk, on Disko Island and in Upernavik (Table 2).

In situ microhabitat temperatures measured by loggers in the period August 2012 to August 2013 were highly variable at all locations (Fig. 3a). The highest measured temperature was $36.36^{\circ} \mathrm{C}$ recorded on June 112013 on Disko Island, and the minimum was $-13.09^{\circ} \mathrm{C}$ on December 12 in Upernavik (Fig. 3a). Logged microhabitat temperature fluctuations gradually decreased over winter and were small at all locations (Fig. 3a). On Disko Island, temperatures only fluctuated between $-5.79^{\circ} \mathrm{C}$ and $-3.42^{\circ} \mathrm{C}$ between February and May compared to between $-0.91^{\circ} \mathrm{C}$ and $36.36^{\circ} \mathrm{C}$ in June (Fig. 3b). Annual average microhabitat temperatures were higher compared to atmospheric temperatures measured by weather stations (e.g. $0.94^{\circ} \mathrm{C}$ compared to $-2.74^{\circ} \mathrm{C}$ on Disko Island) (Fig. 3). In winter and spring (December to May), logger temperature from the microhabitat was $-3.07^{\circ} \mathrm{C}$ compared to $-8.04^{\circ} \mathrm{C}$ measured at the weather station on Disko Island.

Table 1. Collection height and mean, minimum and maximum aerial exposure time in the mid-intertidal level (MTL), $30 \mathrm{~cm}$ below MTL (MTL - 30) and in the lowest tidal zone (LTZ) at the 5 studied locations. Different heights of MTL are caused by regional differences in the tidal amplitude

\begin{tabular}{|lccccc|}
\hline \multirow{2}{*}{ Location } & \multirow{2}{*}{ Position } & $\begin{array}{c}\text { Intertidal } \\
\text { height }(\mathrm{cm})\end{array}$ & \multicolumn{3}{c}{ Daily exposure time $\left(\mathrm{h} \mathrm{d}^{-1}\right)$} \\
& & Mean & Min. & Max. \\
\hline Nuuk & MTL & 250 & 6.5 & 6.0 & 7.2 \\
Disko Island & MTL & 130 & 5.8 & 4.7 & 18.2 \\
Uummannaq & MTL & 120 & 10.2 & 4.8 & 19.2 \\
Upernavik & MTL & 90 & 7.4 & 7.0 & 16.5 \\
& MTL - 30 & 60 & 4.4 & 4.7 & 6.2 \\
Qaanaaq & MTL & 170 & 6.7 & 6.2 & 7.9 \\
& MTL - 30 & 140 & 5.2 & 2.5 & 5.8 \\
& LTZ & $0-100$ & $0-3.5$ & $0-0.5$ & $0-4.7$ \\
\hline
\end{tabular}

Table 2. The number of days with temperatures measured below $-13^{\circ} \mathrm{C}$ in recent decades (start year depended on availability of data). Significant values of the regression slopes are indicated in bold

\begin{tabular}{|c|c|c|c|c|}
\hline \multirow[t]{2}{*}{ Location } & \multicolumn{2}{|c|}{ Days below $-13^{\circ} \mathrm{C}$} & \multirow{2}{*}{$\begin{array}{l}\text { Regression } \\
\text { slope }\end{array}$} & \multirow[t]{2}{*}{$\mathrm{p}$} \\
\hline & Start & End & & \\
\hline Nuuk & 39 (1990) & 18 (2011) & -2.179 & $<0.0001$ \\
\hline Disko Island & 134 (1990) & 94 (2011) & -2.681 & 0.0035 \\
\hline Uummannaq & $95(2002)$ & 41 (2011) & -1.667 & 0.94 \\
\hline Upernavik & 141 (1991) & $103(2011)$ & -2.394 & 0.0010 \\
\hline Qaanaaq & 173 (1996) & 169 (2011) & -0.055 & 0.95 \\
\hline
\end{tabular}



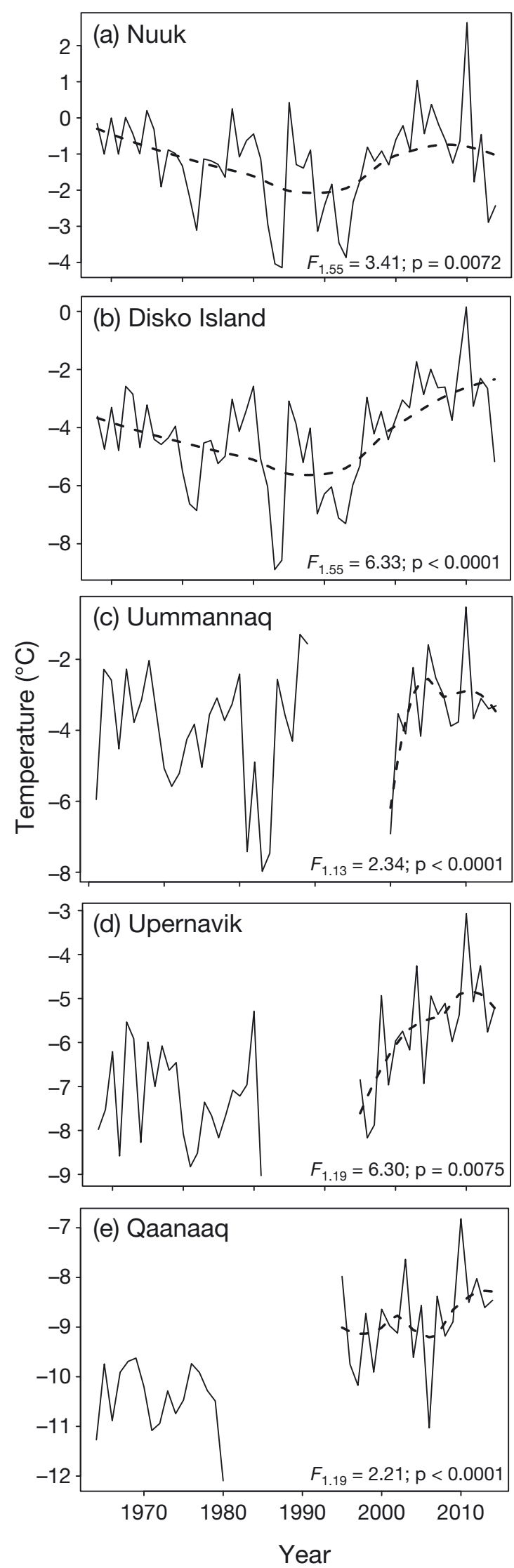

Fig. 2. Annual mean atmospheric temperatures measured at weather stations from the 5 sampling locations: (a) Nuuk, (b) Disko Island, (c) Uummannaq, (d) Upernavik and (e) Qaanaaq. The generalized additive models F-statistics are indicated with the associated p-value

\section{Abundance and recruitment}

A total of 5320 specimens were collected within the size range of $0.8-72.5 \mathrm{~mm}$. At the $\mathrm{MTL}$, mussels were found in all locations along west Greenland from Nuuk to Upernavik (Fig. 4). The highest mean ( \pm SE) density was found in Nuuk (23.67 \pm 4.92 ind. 0.0625 $\mathrm{m}^{-2}$ ) and gradually declined towards the northern edge of the geographic range (Model 1 in Supplement 4, Fig. 4a). There was a significant effect of tidal height on abundance in both Upernavik and Qaanaaq (Table 3). In Upernavik, mussels were statistically significantly more abundant at MTL $-30 \mathrm{~cm}$

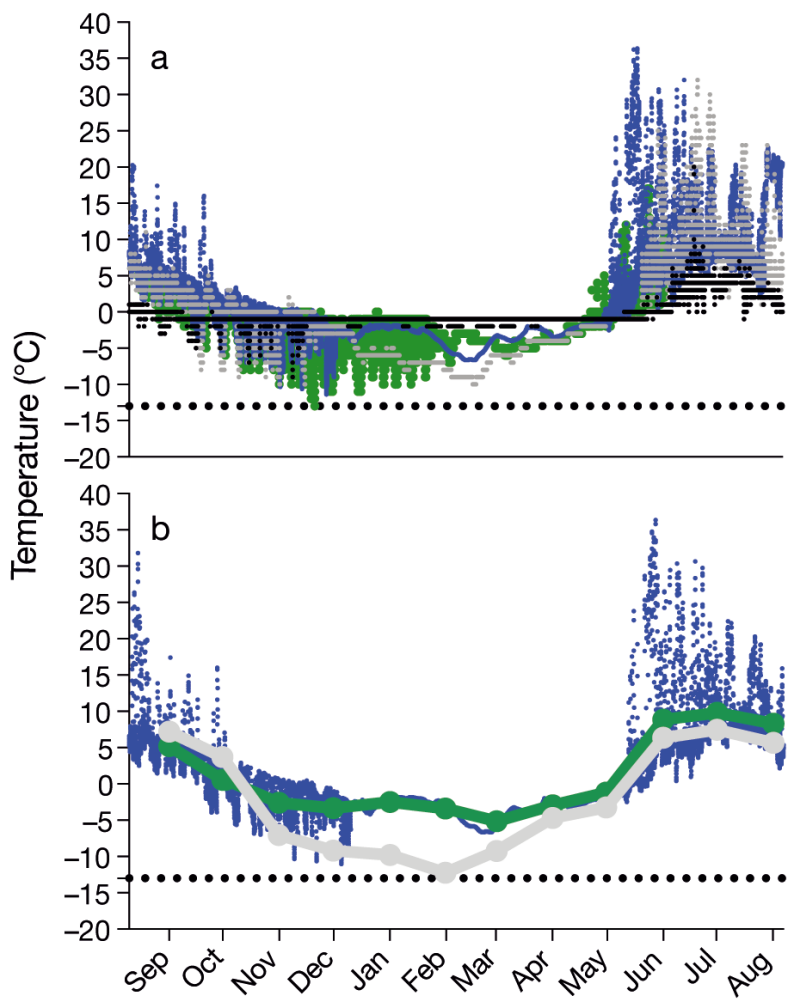

Fig. 3. (a) Microhabitat temperatures measured within the intertidal zone at 4 locations in west Greenland: Disko Island (blue dots), Uummannaq (grey dots), Upernavik (green dots) and Qaanaaq (black dots). (b) Atmospheric air temperatures measured every 15 min (blue dots) at the midintertidal level (MTL) on Disko Island in 2012-2013. Monthly mean temperatures measured at the MTL (green line) and at nearby weather station (DMI station no. 4221) (grey line) are shown. Horizontal dotted line indicates lower lethal temperature $\left(-13^{\circ} \mathrm{C}\right)$ 

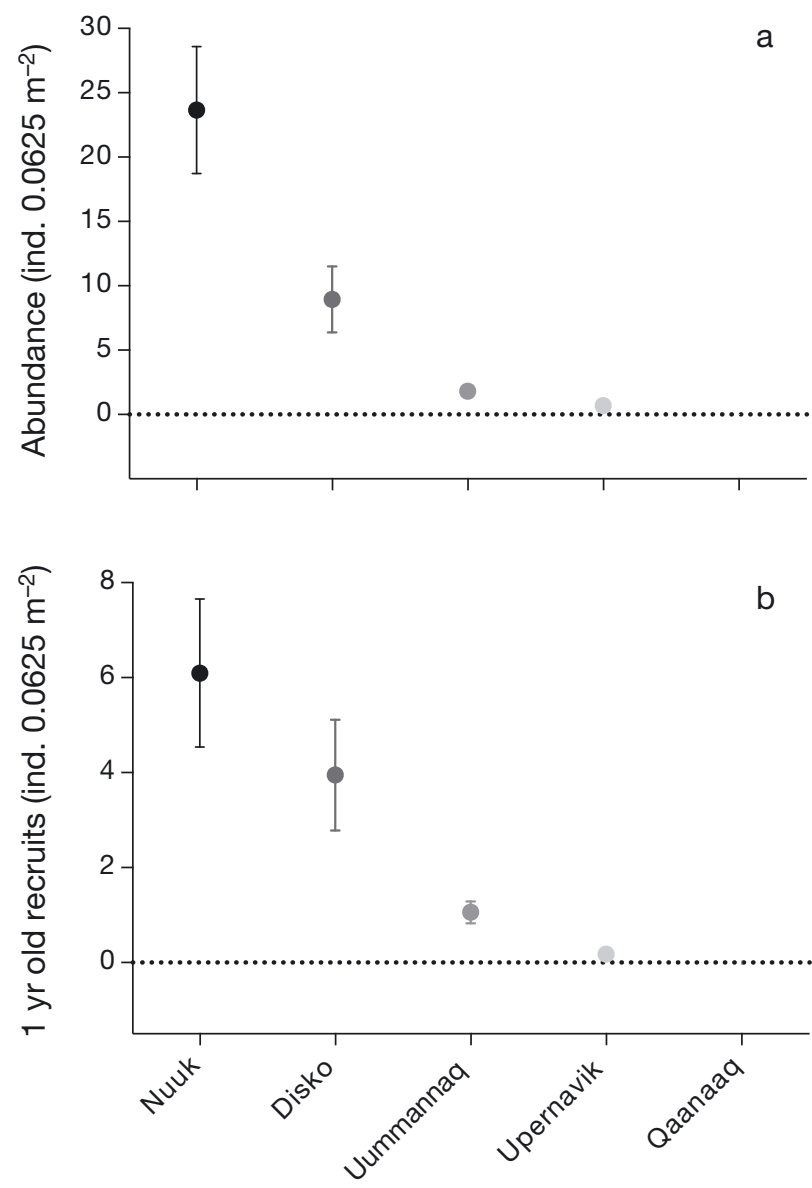

Fig. 4. Average abundances of (a) adult Mytilus and (b) 1 yr old recruits at the mid-intertidal level at the 5 sampling locations. No mussels were found in Qaanaaq. Error bars indicate $\pm \mathrm{SE}$

Table 3. Intertidal abundances of Mytilus at the 5 sampling locations. Data are mean \pm SE. See Table 1 for position abbreviations

\begin{tabular}{|lcc|}
\hline Location & Position & Abundance \\
\hline Nuuk & MTL & $23.67 \pm 4.92$ (ind. $0.0625 \mathrm{~m}^{-2}$ ) \\
Disko Island & MTL & $8.94 \pm 2.57$ (ind. $0.0625 \mathrm{~m}^{-2}$ ) \\
Uummannaq & MTL & $1.82 \pm 0.40$ (ind. $0.0625 \mathrm{~m}^{-2}$ ) \\
Upernavik & MTL & $0.71 \pm 0.33$ (ind. $0.0625 \mathrm{~m}^{-2}$ ) \\
& MTL -30 & $15.87 \pm 7.17$ (ind. $0.0625 \mathrm{~m}^{-2}$ ) \\
Qaanaaq & MTL & - \\
& MTL $-30^{\mathrm{a}}$ & - \\
& LTZ & $5.91 \pm 0.51$ (ind. $\mathrm{m}^{-2}$ ) \\
aNo mussels were found & \\
\hline
\end{tabular}

compared to MTL (GLM, p < 0.0001; Table 3), and in Qaanaaq, individuals were only found in the lowest tidal zone (LTZ) where the air exposure time was short (max. $4.7 \mathrm{~h}$ ) and average winter temperature was $-1.8^{\circ} \mathrm{C}$. The density of $1 \mathrm{yr}$ old recruits also significantly decreased with increasing latitude (Model 2 in Supplement 4, Fig. 4b). Mean $( \pm \mathrm{SE})$ numbers of $1 \mathrm{yr}$ old recruits declined from $6.09 \pm 0.74$ ind. $0.0625 \mathrm{~m}^{-2}$ in Nuuk to $0.18 \pm 0.01$ ind. $0.0625 \mathrm{~m}^{-2}$ in Upernavik (no $1 \mathrm{yr}$ old recruits were found in Qaanaaq).

\section{Age distribution and mortality}

Age structure varied significantly between all locations (Kruskal-Wallis; $\chi^{2}=30.22, \mathrm{p}<0.0001$ ). The age distribution ranged from 15 age classes in Nuuk to 6 in Upernavik at the MLT (Fig. 5). Regardless of location, all populations were consistently dominated by young individuals, especially the previous year's settlement (age $\leq 2$ ), which constituted $>50 \%$ of all populations (Fig. 5). Newly settled spat were found at the MTL on Disko Island, Uummannaq and Upernavik (Fig. 5b-d). Nuuk samples had no spat because collections were conducted in early June before spawning and larval settlement (Fig. 5a). At MTL - 30, the Upernavik population consisted of 6 age classes (Fig. 5e), and in the LTZ in Qaanaaq, the age ranged from 2 to 13 (Fig. 5f).

MTL specimens older than 10 yr were found only in Nuuk (Table 4). The highest estimated mortality rates were in Uummannaq $(Z=0.98, \mathrm{p}=0.0004)$, while the lowest was found in Nuuk in age 10 to 15 mussels $(Z=0.12, \mathrm{p}=0.1775)$. We did not estimate mortality rates for MTL in Upernavik because we consider this $Z$ estimate as uncertain due to the low number of observations (65 individuals). The estimated mortality rates were $Z=0.94(\mathrm{p}=0.0008)$ and $Z=0.41(\mathrm{p}=0.0042)$ in Upernavik MLT -30 and Qaanaaq LTZ, respectively.

\section{Shell length-at-age}

Shell length-at-age data from the localities were used to estimate growth. The initial growth model involved 6 parameter values to each group by maximizing the joint likelihood. We reduced this model in single steps to test if some parameters could be applied to all groups. None of the 6 growth model parameters could be fitted by the same value to all groups without changing the individual growth curve characteristics statistically significantly $(p<$ 0.0001). In its essence, this means that growth patterns differed between groups. However, it seemed that (1) Nuuk and Qaanaaq and (2) Disko Island, 
(a) Nuuk MTL
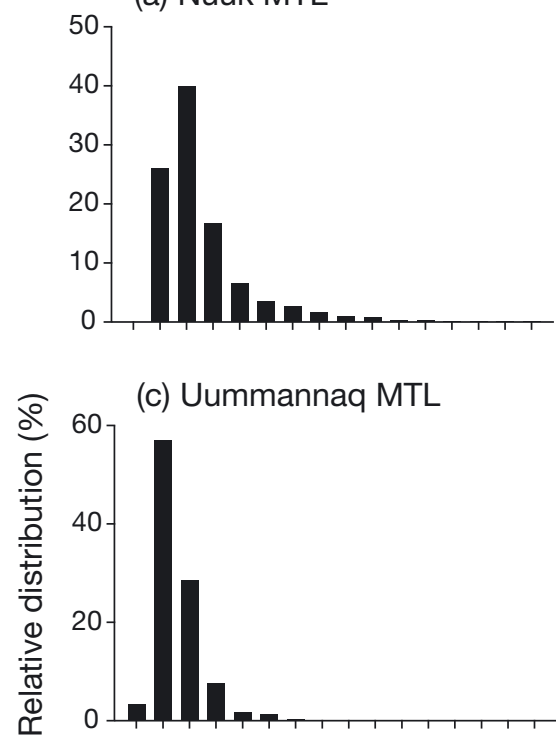

(e) Upernavik MTL - 30

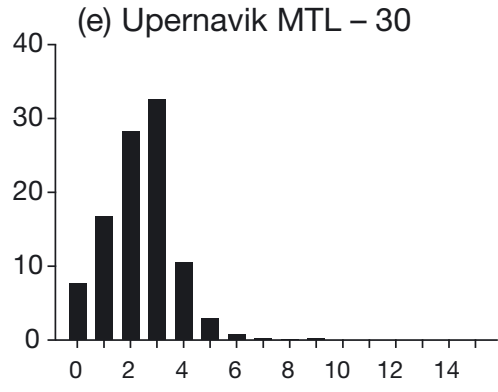

Fig. 5. Relative age distributions of Mytilus at the mid-intertidal level (MTL) in (a) Nuuk, (b) Disko Island, (c) Uummannaq, (d) Upernavik, (e) $30 \mathrm{~cm}$ below the MTL (MTL - 30) in Upernavik and (f) in the lowest tidal zone (LTZ) in Qaanaaq

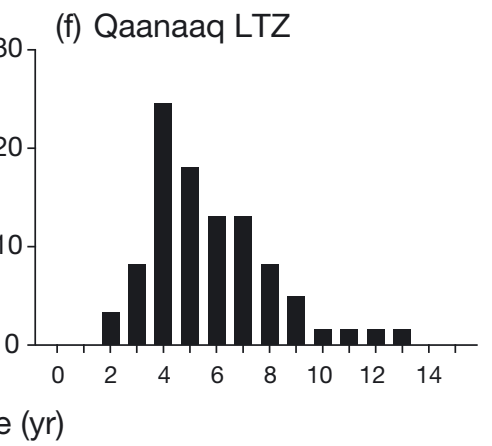

(b) Disko Island MTL

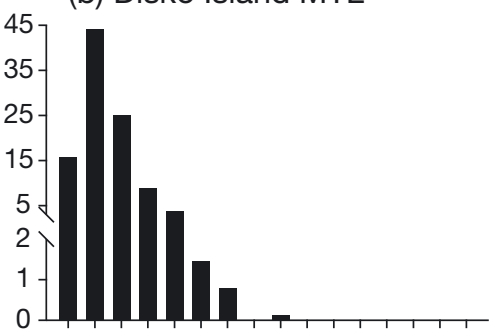

(d) Upernavik MTL

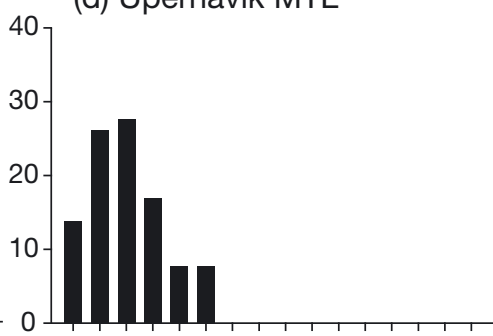

\section{.} rates with an asymptotic shell length $S$ of $>50 \mathrm{~mm}$. However individual maximum shell length ranged from

Table 4. Average shell size and age, maximum age, and estimates of the mortality rate $(Z)$ and annual mortality $\left(1-\mathrm{e}^{-Z}\right)$ of Mytilus from the mid-intertidal level (MTL) at the 5 locations. The annual mortality was not estimated for Qaanaaq age $<5$ and $>10$ and Upernavik MTL due to a low number of observations

\begin{tabular}{|c|c|c|c|c|c|c|}
\hline Location & Position & $\begin{array}{l}\text { Average } \\
\text { size }(\mathrm{mm})\end{array}$ & $\begin{array}{l}\text { Average } \\
\text { age (yr) }\end{array}$ & $\begin{array}{l}\text { Maximum } \\
\text { age (yr) }\end{array}$ & $Z$ estimate & $\begin{array}{c}\text { Annual mortality } \\
\left(\% \mathrm{yr}^{-1}\right)\end{array}$ \\
\hline Nuuk & MTL & 8.97 & 2.5 & 15 & $\begin{array}{c}0.82 \text { (age } 2-5 \text { ) } \\
0.48 \text { (age } 5-10 \text { ) } \\
0.12 \text { (age } 10-15 \text { ) }\end{array}$ & $\begin{array}{l}55.94 \\
38.12 \\
11.31\end{array}$ \\
\hline Disko Island & MTL & 7.29 & 1.5 & 8 & 0.84 (age $1-8$ ) & 56.83 \\
\hline Uummannaq & MTL & 6.32 & 1.5 & 6 & 0.98 (age 1-6) & 62.47 \\
\hline Upernavik & $\begin{array}{c}\text { MTL } \\
\text { MTL - } 30\end{array}$ & $\begin{array}{l}7.62 \\
8.88\end{array}$ & $\begin{array}{c}2 \\
2.37\end{array}$ & $\begin{array}{l}5 \\
9\end{array}$ & $\frac{-}{0.94 \text { (age 3-9) }}$ & $\stackrel{-}{61.16}$ \\
\hline Qaanaaq & $\begin{array}{c}\text { MTL }^{\mathrm{a}} \\
\text { MTL }-30^{\mathrm{a}} \\
\text { LTZ }\end{array}$ & $\begin{array}{c}- \\
- \\
21.79\end{array}$ & $\begin{array}{l}- \\
- \\
5.75\end{array}$ & $\begin{array}{l}- \\
- \\
13\end{array}$ & $\begin{array}{c}- \\
- \\
0.46(\text { age } 5-10)\end{array}$ & $\begin{array}{c}- \\
- \\
37.04\end{array}$ \\
\hline
\end{tabular}


Table 5. Growth model parameters for Mytilus from the 5 locations. $S_{\infty}$ : asymptotic shell length $(\mathrm{mm})_{i} t_{*}$ : age-at-growth inflexion; $T$ : time required to grow from zero to $S_{\infty}$ at maximum growth rate; $m$ : shape factor for growth curves; $a$ and $b$ : parameters in the error term

\begin{tabular}{|lccccccc|}
\hline Location & Position & $S_{\infty}$ & $t_{*}$ & $T$ & $m$ & $a$ & $b$ \\
\hline Nuuk & MTL & 53.356 & 4.126 & 10.109 & 0.752 & 0.313 & 1.000 \\
Disko Island & MTL & 25.002 & 2.729 & 5.304 & 1.891 & 0.342 & 0.769 \\
Uummannaq & MTL & 25.002 & 2.906 & 4.990 & 1.891 & 0.520 & 0.793 \\
Upernavik & MTL & 25.002 & 3.698 & 7.346 & 1.891 & 0.131 & 1.176 \\
& MTL - 30 & 25.002 & 3.344 & 6.354 & 1.891 & 0.331 & 0.718 \\
Qaanaaq & MTL & - & - & - & - & - & - \\
& MTL - 30 & - & - & - & - & - & - \\
& LTZ & 53.356 & 4.562 & 10.383 & 0.752 & 1.004 & 0.499 \\
aNo mussels were found & & & & & & \\
\hline
\end{tabular}
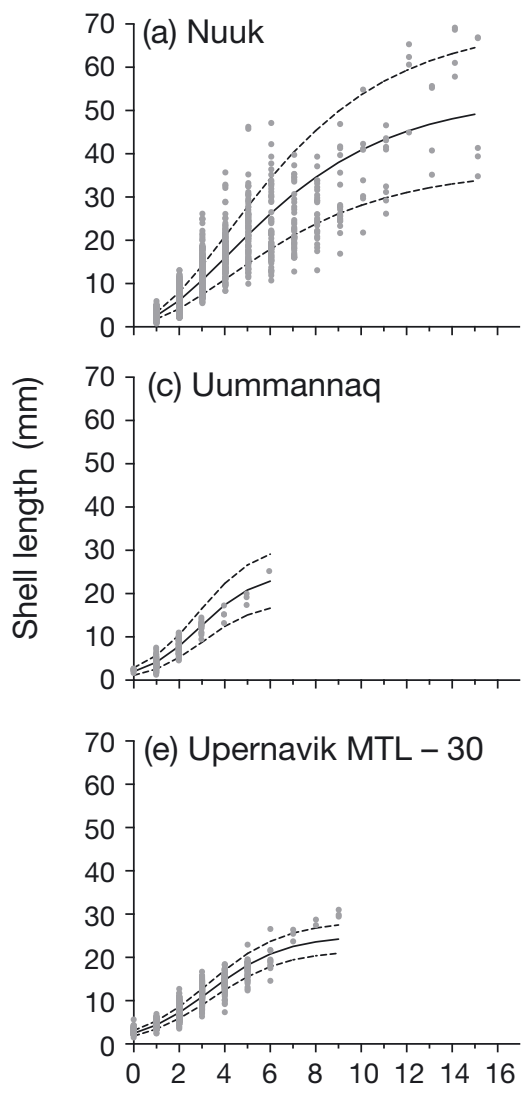

\section{Age (yr)}

Fig. 6. Growth patterns estimated from shell length-at-age data of intertidal Mytilus found in at the 5 sampling locations in west Greenland: (a) Nuuk, (b) Disko Island, (c) Uummannaq, (d) Upernavik and (e) Qaanaaq. See Table 5 for parameter values. Dotted curves indicate standard deviation, and the grey dots indicate the actual measured values for each individual mussel

$<30 \mathrm{~mm}$ to $>70 \mathrm{~mm}$ as a result of large local-scale variations in growth conditions. In comparison, mussels from the other locations experienced an abrupt decrease in growth rates at age $>5$ with an asymp- totic shell length of $\sim 25 \mathrm{~mm}$ and an observed maximum shell length of $32 \mathrm{~mm}$ (Fig. 6).

\section{Cold tolerance}

Air temperature had a significant effect on survival (see Supplement 4). We found a latitudinal difference in $\mathrm{LT}_{50}$ : mussels collected in Uummannaq survived at a lower temperature compared to mussels from Nuuk (Table 6). In terms of size differences, we found that $\mathrm{LT}_{50}$ was lower for large mussels compared to smaller individuals (Table 6). Time of aerial exposure also had a significant effect on the survival rate. Four hours of exposure had a significant effect on $\mathrm{LT}_{50}$ compared to mussels exposed for only $1 \mathrm{~h}$ (Table 6). Finally, we found a statistically significant seasonal difference (Table 6) with spring-acclimated mussels being more cold-tolerant compared to summeracclimated mussels.

\section{DISCUSSION}

\section{Latitudinal changes in population dynamics of Mytilus in Greenland}

We observed a clear large-scale latitudinal decline in Mytilus abundance from $64^{\circ}$ to $77^{\circ} \mathrm{N}$ in west Greenland. This correlated to the decline in atmospheric temperatures measured along the north-south climate gradient. The average abundance decreased by $>95 \%$ at the MLT from Nuuk (average 23.67 ind. $0.0625 \mathrm{~m}^{-2}$ ) to Upernavik (average 0.71 ind. $0.0625 \mathrm{~m}^{-2}$ ). The difference between Nuuk and Upernavik abundances was found already at the stage of 1 yr old recruits, with no subsequent latitudinal increase in adult mortality rates. Thus, our results suggest the latitudinal decline in abundance could be caused by decreasing larval supply or increasingly high mortality rates in vulnerable early life stages 
Table 6. Lower average lethal temperatures causing $50 \%$ mortality $\left(\mathrm{LT}_{50}\right)$ in Mytilus from west Greenland. Latitude $64^{\circ} \mathrm{N}$ except for Uummannaq at $70^{\circ} \mathrm{N}$. Standard error presented in parentheses

\begin{tabular}{|c|c|c|c|c|c|}
\hline Variables & $\begin{array}{c}\text { Average } \\
\text { length (mm) }\end{array}$ & $\mathrm{LT}_{50}\left({ }^{\circ} \mathrm{C}\right)$ & $\mathrm{n}$ & $\mathrm{p}$ & Season \\
\hline \multicolumn{6}{|l|}{ Location $^{a}$} \\
\hline Nuuk & 33.1 & $-12.8( \pm 0.18)$ & 10 & & \\
\hline Uummannaq & 30.8 & $-13.5( \pm 0.27)$ & 10 & 0.0001 & Summer \\
\hline \multicolumn{6}{|l|}{ Shell length ${ }^{a}$} \\
\hline Small & 32.1 & $-13.4( \pm 0.19)$ & 10 & & \\
\hline Large & 51.2 & $-13.9( \pm 0.16)$ & 10 & 0.0229 & Summer \\
\hline \multicolumn{6}{|l|}{ Season $^{a}$} \\
\hline Summer & 33.1 & $-12.8( \pm 0.18)$ & 10 & & - \\
\hline Spring & 32.8 & $-13.8( \pm 0.19)$ & 10 & $<0.0001$ & \\
\hline \multicolumn{6}{|l|}{ Exposure time } \\
\hline 1 hour & 30.4 & $-13.4( \pm 0.19)$ & 10 & & Summer \\
\hline 2 hours & 33.1 & $-12.8( \pm 0.18)$ & 10 & 0.0502 & \\
\hline 4 hours & 32.1 & $-12.4( \pm 0.16)$ & 10 & $<0.0001$ & \\
\hline
\end{tabular}

(spat and 1 yr). In support, Lewis (1986) concluded that northern limits of molluscs along the west Atlantic coast are determined by the sensitivity of newly settled spat to low temperatures. Unfortunately, we were unable to estimate mortalities of spat and 1 yr old recruits because there was a lower than expected abundance of these in our data set. There are also alternative explanations for the observed decline in abundance. For example, intertidal ice scour is more prevalent at higher latitudes, hereby removing more spat compared to southern locations where sea ice is less pronounced (Heaven \& Scrosati 2008).

The space-for-time approach used in this study is suitable to infer temporal changes from spatial patterns (Blois et al. 2013). The method can potentially underestimate changes in highly complex habitats as it neglects fine-scale heterogeneity (Pickett 1989). However, we applied a large-scale high-resolution sampling design in a relatively species-poor intertidal habitat and suggest that a warmer future will likely increase abundances of Mytilus. For instance, current densities on Disko Island constitute $\sim 37 \%$ of the densities found in Nuuk; thus, we can use conditions in Nuuk as a first approximation of what abundances on Disko Island may be like in the future. The future temperature increases could also threaten intertidal populations of mussels in southern Greenland; we found temperatures exceeding $36^{\circ} \mathrm{C}$ during extreme events of solar radiation at low tide. This is above the upper thermal limit of Mytilus $\left(\sim 32^{\circ} \mathrm{C}\right)$
(Jones et al. 2010). So, although body temperatures of intertidal organisms may differ from the unprotected loggers used in this study, our results suggest that in a warmer future, heat-induced stress/mortality could become more common in the Arctic. Therefore, future climate change research should focus on the potential for heat stress in coldadapted Arctic organisms.

\section{Effects of local-scale variation in environmental drivers}

The abundance and growth of Mytilus was highly variable within and among fjords. Among fjords, exposure time is central for the effects of air temperatures on the survival of intertidal species (Helmuth et al. 2006). We found a large variation in periods of aerial exposure among and within fjords (Table 1) caused by local tidal cycles and bathymetry. Differences in the timing and duration of the low tide are therefore important for shaping the populations in Greenland (Helmuth \& Hofmann 2001, Helmuth et al. 2006). For example, the abundance in Uummannaq was lower than on Disko Island even though Disko Island annually has $94 \mathrm{~d}$ with temperatures below $-13^{\circ} \mathrm{C}$ compared to $41 \mathrm{~d}$ in Uummannaq. This result contradicts the large-scale temperature-abundance correlation described above. However, the average exposure time during low tide in Uummannaq is $10.2 \mathrm{~h}$ compared to $5.8 \mathrm{~h}$ on Disko Island. Thus, the prolonged exposure time in Uummannaq likely increases mortality and affects recruitment success (Lewis 1986, Helmuth 1999).

Within fjords, patchy abundances were due to mussels rarely being found on smooth surfaces. Instead they were concentrated in microhabitats between boulders, in crevices or underneath macroalgae. Such microhabitats retain moisture and provide a refuge from extreme temperatures and desiccation (Seed 1969, Helmuth et al. 2006). For instance, on Disko Island, the average microhabitat temperature in February was $9.1^{\circ} \mathrm{C}$ warmer than the atmospheric average $\left(-3.40^{\circ} \mathrm{C}\right.$ compared to $\left.-12.57^{\circ} \mathrm{C}\right)$. These temperature patterns are caused by the formation of intertidal ice and macroalgae that creates a protective layer during winter (Scrosati \& Eckersley 2007). Thus, this study highlights the importance of 
studying climatic (e.g. temperatures) and non-climatic (e.g. tidal cycles) parameters on a within- (small-) and between-fjord (meso-) scale to understand largescale species abundance, recruitment, settlement and population structures. This is supported by previous work demonstrating the intertidal zone is characterized by interactions of overlapping environmental factors including sub-zero air and water temperatures, annual primary productivity, $\mathrm{pH}$, wave exposure, air exposure time, ice scour, solar radiation and rugosity (Helmuth et al. 2006, Kroeker et al. 2016).

\section{The importance of cold tolerance}

Biotic interactions seem limited in the intertidal zone in Greenland as no predators are found. Hence biological patterns are controlled primarily by physical (see discussion above) and physiological factors, and secondarily by resource availability (Blicher et al. 2013, Høgslund et al. 2014). Because Mytilus are semi-sessile animals, they rely on cold tolerance to survive sub-zero temperatures (Thyrring et al. 2015a). Following exposure to 1 cycle of sub-zero air temperatures, mussels displayed a significantly different $\mathrm{LT}_{50}$ on a temporal and spatial scale. Thus, our results show physiological distinct adaptations among populations and seasons (Braby \& Somero 2006, Kuo $\&$ Sanford 2009). The ability to adjust thermal tolerance combined with suitable habitat use are important in reducing local mortality of intertidal populations (Southward 1958). It should be noted that we did not include genetic analysis in the cold tolerance experiments, and subtle differences in ecology and physiology among Mytilus spp. congeners cannot be distinguished here but should be studied further. Furthermore, thermal tolerance is affected by the thermal history and times of exposure. For instance, the upper lethal limit of the blue mussel $M$. edulis decreased after repeated exposure to sub-lethal high air temperatures (Jones et al. 2009). Therefore, the results presented here cannot be used to define species ranges based on thermal tolerance (as it is done using correlative species distribution models [Elith \& Leathwick 2009]), but illustrate the capacity of mussels to adapt to their local environment.

\section{Growth rates of Mytilus mussels in Greenland}

The shell growth models based on length-at-age data indicated that mussels had different growth pat- terns among locations. Large variability in growth patterns is common among populations on local and large scale and can be affected by habitat, food availability or environmental stress. For instance, variation in growth patterns of Mytilus at the MTL over the scale of kilometers in the Nuuk area is comparable to the variation found among mussel populations across the entire North Atlantic region (Blicher et al. 2013). The lack of a clear latitudinal decline in growth patterns supports this statement, and interestingly, we found that Mytilus inhabiting favourable habitats can sustain similar growth rates regardless of latitude. We argue, therefore, that the growth patterns obtained from shell length-at-age data from natural populations are not the most sensitive climate effect indicator because environmental conditions restrict animals to sub-optimal habitats with highly variable growth conditions, thus weakening any latitudinal signal (Sukhotin et al. 2007, Blicher et al. 2013). However, the higher asymptotic shell length $\left(S_{\infty}\right)$ found in Nuuk may still indicate a latitudinal signal that could be caused by a positive effect of the longer productive season in the Nuuk area compared to higher-latitude locations (Sejr et al. 2009). Similarly, the higher $S_{\infty}$ found in mussels from the Qaanaaq LTZ demonstrate the positive effect of a shorter air exposure time ( 0 to max. $4.7 \mathrm{~h}$ ) in the low intertidal, which allow submerged filter-feeding organisms to feed for longer periods of the day (i.e. higher growth potential) compared to animals found higher in the intertidal zone. But the observed maximum shell length may obviously also be related to the observed maximum age, which again is linked to recruitment and mortality. Our estimates of maximum age at the MTL tend to show latitudinal clines (Table 4). Thus, the same local abiotic and biotic stressors affecting abundance and mortality (as discussed above) also affect growth in intertidal mussels. However, growth seems to be a more sensitive parameter to local-scale drivers, and hence we conclude that abundance and age structure are better indicators for studying regional patterns.

\section{CONCLUSION}

By substituting space for time, we present the first quantitative study of Mytilus abundances, growth and age structure along a latitudinal climate gradient in intertidal west Greenland. The spatial comparison showed that mussels are most abundant in southern populations, and a vertical retraction to the lower intertidal zone was found at northern sites. We found 
a significant local and seasonal thermal adaptation to low air temperatures, but Mytilus required microhabitats for protection from low lethal air temperatures and desiccation at all locations. Our data show that adult mortality rates are not increasing with latitude. Instead, differences in the survival in the vulnerable early life stages of mussels (spat to $1 \mathrm{yr}$ ) and/or in larval supply are responsible for the observed latitudinal decrease in abundance. Because air temperatures are expected to continue to increase in the coming decades, our results suggest that a future warming will allow Mytilus in Greenland and across the Arctic to generally increase abundances within the limits set by variable local-scale stressors as well as the mussels' ability to spread and the potential temperature sensitivity of early life stages. This trend stands in contrast to temperate regions where Mytilus abundances are declining (Sorte et al. 2017), and because Mytilus are foundation species providing habitats, future potential expansions will have cascading effects on the intertidal community.

Acknowledgements. This study was financially supported by a grant from 15. Juni Fonden, the Mineral License and Safety Authority (MLSA), the Environmental Agency for Mineral Resource Activities (EAMRA) of Greenland and the Danish Cooperation for Environment in the Arctic (DANCEA). We also thank 3 anonymous reviewers for constructive comments and valuable feedback on earlier drafts. The authors gratefully acknowledge the contribution of the Arctic Research Centre (ARC). This work is a contribution to the Arctic Science Partnership (ASP).

\section{LITERATURE CITED}

AMAP (2017) Snow, water, ice and permafrost in the Arctic (SWIPA). Summary for policy-makers, Oslo, Norway

Berry DA, Lindgren BW (1996) Statistics, theory and methods, 2nd edn. Duxbury Press, Belmont, CA

Blicher ME, Rysgaard S, Sejr MK (2007) Growth and production of sea urchin Strongylocentrotus droebachiensis in a high-Arctic fjord, and growth along a climatic gradient (64 to $77^{\circ}$ N). Mar Ecol Prog Ser 341:89-102

Blicher ME, Sejr MK, Høgslund S (2013) Population structure of Mytilus edulis in the intertidal zone in a sub-Arctic fjord, SW Greenland. Mar Ecol Prog Ser 487:89-100

Blois JL, Williams JW, Fitzpatrick MC, Jackson ST, Ferrier S (2013) Space can substitute for time in predicting climate-change effects on biodiversity. Proc Natl Acad Sci USA 110:9374-9379

Boas L, Wang R (2011) Weather and climate data from Greenland 1958-2010-Observation data with description. Technical Report 11-15. Danish Meteorological Institute, Copenhagen

Braby CE, Somero GN (2006) Following the heart: temperature and salinity effects on heart rate in native and invasive species of blue mussels (genus Mytilus). J Exp Biol 209:2554-2566
Elith J, Leathwick JR (2009) Species distribution models: ecological explanation and prediction across space and time. Annu Rev Ecol Evol Syst 40:677-697

* Griffiths GM, Chambers LE, Haylock MR, Manton MJ and others (2005) Change in mean temperature as a predictor of extreme temperature change in the Asia-Pacific region. Int J Climatol 25:1301-1330

Gutiérrez JL, Jones CG, Byers JE, Arkema KK and others (2011) Physical ecosystem engineers and the functioning of estuaries and coasts. In: Wolanski E, Mclusky DS (eds) Treatise on estuarine and coastal science, Book 7. Academic Press, Waltham, p 53-81

Hansen L (1999) The intertidal macrofauna and macroalgae at 5 Arctic localities (Disko, West Greenland). In: Brandt A, Thomsen HA, Heide-Jorgensen H, Kristensen RM, Ruhberg H (eds) The 1998 Danish-German excursion to Disko Island, West Greenland, Book 330. Alfred Wegener Institut für Polar und Meeresforschung, Bremerhaven, p 92-110

Harley CDG (2011) Climate change, keystone predation, and biodiversity loss. Science 334:1124-1127

* Heaven CS, Scrosati RA (2008) Benthic community composition across gradients of intertidal elevation, wave exposure, and ice scour in Atlantic Canada. Mar Ecol Prog Ser 369:13-23

* Helmuth B (1999) Thermal biology of rocky intertidal mussels: quantifying body temperatures using climatological data. Ecology 80:15-34

Helmuth BST, Hofmann GE (2001) Microhabitats, thermal heterogeneity, and patterns of physiological stress in the rocky intertidal zone. Biol Bull 201:374-384

*Helmuth B, Broitman BR, Blanchette CA, Gilman SE and others (2006) Mosaic patterns of thermal stress in the rocky intertidal zone: implications for climate change. Ecol Monogr 76:461-479

*Høgslund S, Sejr MK, Wiktor J Jr, Blicher ME, Wegeberg S (2014) Intertidal community composition along rocky shores in South-west Greenland: a quantitative approach. Polar Biol 37:1549-1561

Jones SJ, Mieszkowska N, Wethey DS (2009) Linking thermal tolerances and niogeography: Mytilus edulis (L.) at its southern limit on the east coast of the United States. Biol Bull 217:73-85

Jones SJ, Lima FP, Wethey DS (2010) Rising environmental temperatures and biogeography: poleward range contraction of the blue mussel, Mytilus edulis L., in the western Atlantic. J Biogeogr 37:2243-2259

Kostylev V, Erlandsson J (2001) A fractal approach for detecting spatial hierarchy and structure on mussel beds. Mar Biol 139:497-506

Krause-Jensen D, Marba N, Olesen B, Sejr MK and others (2012) Seasonal sea ice cover as principal driver of spatial and temporal variation in depth extension and annual production of kelp in Greenland. Glob Change Biol 18:2981-2994

Kroeker KJ, Sanford E, Rose JM, Blanchette CA and others (2016) Interacting environmental mosaics drive geographic variation in mussel performance and predation vulnerability. Ecol Lett 19:771-779

*Kuo ESL, Sanford E (2009) Geographic variation in the upper thermal limits of an intertidal snail: implications for climate envelope models. Mar Ecol Prog Ser 388: $137-146$

KLewis JR (1986) Latitudinal trends in reproduction, recruitment and population characteristics of some rocky lit- 
toral mollusks and cirripedes. Hydrobiologia 142:1-13

Marbà N, Krause-Jensen D, Olesen B, Christensen PB and others (2017) Climate change stimulates the growth of the intertidal macroalgae Ascophyllum nodosum near the northern distribution limit. Ambio 46:119-131

Mathiesen SS, Thyrring J, Hemmer-Hansen J, Berge J and others (2017) Genetic diversity and connectivity within Mytilus spp. in the subarctic and Arctic. Evol Appl 10: 39-55

McCullagh P, Nelder JA (1989) Generalized linear models, 2nd edn. Chapman \& Hall, London

Nuismer SL, Gandon S (2008) Moving beyond commongarden and transplant designs: insight into the causes of local adaptation in species interactions. Am Nat 171: 658-668

Pickett STA (1989) Space-for-time substitution as an alternative to long-term studies. In: Likens GE (ed) Long-term studies in ecology. Springer-Verlag, New York, NY, p 110-135

Pimm SL, Jenkins CN, Abell R, Brooks TM and others (2014) The biodiversity of species and their rates of extinction, distribution, and protection. Science 344:1246752

Poloczanska ES, Burrows MT, Brown CJ, García Molinos J and others (2016) Responses of marine organisms to climate change across oceans. Front Mar Sci 3:62

R Core Team (2017) R: a language and environment for statistical computing. R Foundation for Statistical Computing, Vienna

Richards FJ (1959) A flexible growth function for empirical use. J Exp Bot 10:290-300

Scrosati R, Eckersley LK (2007) Thermal insulation of the intertidal zone by the ice foot. J Sea Res 58:331-334

Seed R (1969) The ecology of Mytilus edulis L. (Lamellibranchiata) on exposed rocky shores. I. Breeding and settlement. Oecologia 3:277-316

Sejr MK, Blicher ME, Rysgaard S (2009) Sea ice cover affects inter-annual and geographic variation in growth of the Arctic cockle Clinocardium ciliatum (Bivalvia) in Greenland. Mar Ecol Prog Ser 389:149-158

Sorte CJB, Williams SL, Carlton JT (2010) Marine range shifts

Editorial responsibility: Lisandro Benedetti-Cecchi,

Pisa, Italy and species introductions: comparative spread rates and community impacts. Glob Ecol Biogeogr 19:303-316

* Sorte CJB, Davidson VE, Franklin MC, Benes KM and others (2017) Long-term declines in an intertidal foundation species parallel shifts in community composition. Glob Change Biol 23:341-352

* Southward AJ (1958) Note on the temperature tolerances of some intertidal animals in relation to environmental temperatures and geographical distribution. J Mar Biol Assoc UK 37:49-66

Sugden LG, Driver EA, Kingsley MCS (1981) Growth and energy consumption by captive mallards. Can J Zool 59: $1567-1570$

* Sukhotin AA, Strelkov PP, Maximovich NV, Hummel H (2007) Growth and longevity of Mytilus edulis (L.) from northeast Europe. Mar Biol Res 3:155-167

*Thyrring J, Juhl BK, Holmstrup M, Blicher ME, Sejr M (2015a) Does acute lead (Pb) contamination influence membrane fatty acid composition and freeze tolerance in intertidal blue mussels in arctic Greenland? Ecotoxicology 24:2036-2042

* Thyrring J, Thomsen MS, Brunbjerg AK, Wernberg $\mathrm{T}$ (2015b) Diversity and abundance of epibiota on invasive and native estuarine gastropods depend on substratum and salinity. Mar Freshw Res 66:1191-1200

WWassmann P, Duarte CM, Agusti S, Sejr MK (2011) Footprints of climate change in the Arctic marine ecosystem. Glob Change Biol 17:1235-1249

Wȩsławski JM, Wiktor J Jr, Kotwicki L (2010) Increase in biodiversity in the arctic rocky littoral, Sorkappland, Svalbard, after 20 years of climate warming. Mar Biodivers 40:123-130

Zuur AF (2012) A beginner's guide to Generalized Additive Models with R. Highland Statistics, Newburgh

* Zuur AF, Ieno EN (2016) A protocol for conducting and presenting results of regression-type analyses. Methods Ecol Evol 7:636-645

* Zuur AF, Ieno EN, Elphick CS (2010) A protocol for data exploration to avoid common statistical problems. Methods Ecol Evol 1:3-14

Submitted: November 21, 2016; Accepted: October 13, 2017 Proofs received from author(s): November 28, 2017 